\title{
NOTAS
}

\section{Thermal behavior of calafate (Berberis buxifolia) seeds}

\author{
Comportamiento térmico de las semillas de calafate (Berberis buxifolia)
}

\author{
Pablo Martín-Ramos a*, Jesús Martín-Gil b, María del Carmen Ramos-Sánchez c, \\ Salvador Hernández-Navarro ${ }^{\text {b }}$, Francisco Javier Martín-Gil ${ }^{c}$

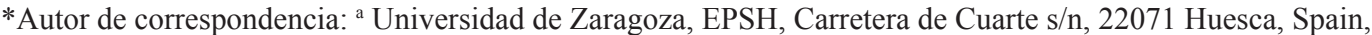 \\ phone: +34 (974) 292668, fax: +34 (974) 239302,pmr@unizar.es

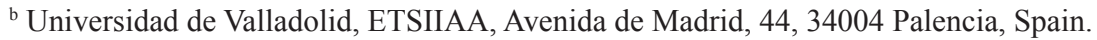 \\ ${ }^{\mathrm{c}}$ Hospital Universitario Río Hortega, Calle Dulzaina 2, 47012 Valladolid, Spain.
}

\begin{abstract}
SUMMARY
Low temperature is the most important factor limiting the distribution of plants. In this study the low temperature thermal behavior of calafate seeds was analyzed by Differential Scanning Calorimetry (DSC), and a vibrational characterization of their different components was conducted by infrared spectroscopy (FTIR). In cold-acclimated plants, such as calafate, the total percentage of polyunsaturated fatty acids in their seeds is significantly higher than that of saturated fatty acids. Successive freezing-thawing cycles lead to increased formation of linoleic (LA) and linolenic (LNA) $\alpha$-crystals. This process would barely modify the phase-transition temperature of the lipid membrane but would lead to an increase in the membrane fluidity (LNA would make the cell membranes more fluid during seed development). It seems that processes in membranes rather than in the glassy cytoplasm may determine the cooling resistance.
\end{abstract}

Key words: $\alpha$-linolenic acid, calafate, DSC, FTIR, seeds.

\section{RESUMEN}

La baja temperatura es el factor limitante más importante cuando se analiza la distribución de las plantas. En este artículo el comportamiento térmico a baja temperatura de las semillas de Berberis buxifolia ha sido estudiado por calorimetría diferencial de barrido y la caracterización de sus diversos componentes ha sido llevada a cabo por espectroscopía infrarroja con transformada de Fourier (FTIR). En plantas aclimatadas al frío, tales como Berberis buxifolia, el porcentaje total de ácidos grasos poliinsaturados en sus semillas es significativamente mayor que el de los ácidos grasos saturados, y sucesivos ciclos de congelación y descongelación conducen a un aumento de la formación de cristales $\alpha$ de linoleico (LA) y linolénico (LNA). Este proceso apenas modificaría la temperatura de transición de fase de la membrana lipídica pero conduciría a un aumento de la fluidez de la misma (el LNA haría las membranas celulares más fluidas durante el desarrollo de las semillas). Es altamente probable que los procesos que tienen lugar en las membranas -en vez de en el citoplasma vítreo- sean los determinantes de la resistencia al frío.

Palabras clave: ácido $\alpha$-linolénico, calafate, calorimetría de barrido diferencial, espectroscopía infrarroja, semillas.

\section{INTRODUCTION}

Berberis buxifolia Lamarck, commonly named "Magellan barberry" or "calafate" (Correa 1984, Rapoport et al. 1999, Ladio 2001, Rapoport et al. 2003), which belongs to the family Berberidaceae, is a cold-tolerant plant that grows above $600 \mathrm{~m}$ as a wild species in many regions of the Patagonian steppe and Subantartic forests (Ratera and Ratera 1980, Correa 1984, Rapoport et al. 1999, Ladio 2001, Rapoport et al. 2003). Calafate easily grows to $3 \mathrm{~m}$ in any humus-rich, well-drained soil in partial shade to full sun.

Its fruits, which have a pleasant flavor, consist of a pulp with many small seeds which are also edible. Fruits of Berberis spp. are also cited as one of the edible wild resources most frequently eaten by the Mapuche community in Patagonia (Ladio 2001), and calafate marmalade, considered a regional Patagonian product, can be commercially obtained in shops oriented to the tourist market.

Calafate fruits can also be fermented to prepare wine (Correa 1984), macerated to obtain strong alcoholic beverages or used for coloring wines (Sztarker and Cattaneo 1976). Calafate commercial tea has been shown to exhibit antimicrobial activity, attributed to the isoquinoline alkaloid berberine, showing inhibitory concentrations similar to those of ampicillin standard (Freile et al. 2006, PittaAlvarez et al. 2008). 
Patagonian people say that the seeds of calafate require a cooling period of several weeks (over 1,000 hours) before germinating in late spring. The verification of this special feature on cooling, adopted as a work hypothesis, aroused our interest to study the thermal behavior of these seeds and the cold-tolerance mechanisms of the plant, which are the main goals of this work. Consequently, in this study a thermal analysis, through Differential Scanning Calorimetry (DSC), has been carried out in order to examine the existence of low temperature thermal effects which could be responsible for such behavior and, in particular, the effect of successive freezing-thawing cycles (analogous to winter ones) on the components involved in the liposomal membrane fluidity.

Obviously, the thermal behavior of calafate seeds should be put in relation to that of their components: vegetal oils, proteins, starch and fiber, which can be identified either by vibrational spectroscopy or by chromatographic techniques. Fourier Transform Infrared Spectroscopy (FTIR) is an excellent tool for a quantitative analysis, offering a practical alternative to time-consuming wet chemical methods and the aforementioned liquid chromatography techniques. To the best of the authors' knowledge, this is the first time that FTIR spectroscopy has been applied to the characterization of calafate seeds, thus fulfilling an additional goal. The existing information in the literature on seed chemical composition indicates that the lipid content (on dry weight basis, $66 \mathrm{mg} \mathrm{g}^{-1}$ seeds) is of about $6.6 \%$ (Sztarker and Cattaneo 1976, Mazzuca et al. 2005), that $\alpha$-linolenic acid (cis-9, cis-12, cis-15-octadecatrienoic acid) ( $\alpha$-LNA) and linoleic acid (cis-9, cis-12-octadecadienoic acid) (LA) are the principal polyunsaturated fatty acids, and that the main monounsaturated one is oleic acid. Palmitic acid, a saturated fatty acid, has been also detected but at a very low concentration. The ratio of polyunsaturated ( $\alpha$-LNA and LA acids) to saturated (palmitic acid) is $6.1: 1$. Sterol composition yields $6.81(0.7 \%) \mathrm{mg} \mathrm{g}^{-1}$ total lipids and includes cholesterol, campesterol, stigmasterol, $\beta$-sitosterol, and stigmasta-5.24(28)-dien-3 $\beta$-ol. Moisture content is $3.7 \%( \pm 0.2)$.

For comparison purposes, Rosa rubiginosa L (rosa mosqueta) seeds and Elaeis guineensis Jacq. (African oil palm) seeds have PUFA (oleic, LA and $\alpha$-LNA) percentages of $77 \%$ and $2 \%$, respectively. While the percentages of carbohydrates and fiber for B. buxifolia seeds were $63 \%$ and $4.7 \%$, respectively; for rosa mosqueta they were $44.2 \%$ and $7.8 \%$, respectively (Dourado et al. 2000); and for palm kernel cake they were $48 \%$ and $9 \%$, respectively (Akinyeye et al. 2011).

\section{METHODS}

Apparatus. Differential scanning calorimetry curves were obtained using a TA Instruments Q100 under $\mathrm{N}_{2}$ flow (20 $\mathrm{mL} \mathrm{\textrm {min } ^ { - 1 } \text { ), at a heating rate of } 2 0 ^ { \circ } \mathrm { C } \mathrm { min }}{ }^{-1}$, in $40-\mu \mathrm{L}$ sealed aluminium capsules (sample mass $m=2.5 \mathrm{mg}$ ). After coo- ling samples down to $-100^{\circ} \mathrm{C}$, the scans were registered on the heating cycle from $-100{ }^{\circ} \mathrm{C}$ to $500{ }^{\circ} \mathrm{C}$. For the study of the glass transition at low temperatures, samples were cooled to $-100{ }^{\circ} \mathrm{C}$ and then heated from $-60{ }^{\circ} \mathrm{C}$ to $+20^{\circ} \mathrm{C}$ at a rate of $10^{\circ} \mathrm{C} \mathrm{min}^{-1}$. The data obtained were analyzed using TA Instruments Universal Analysis V4.1D software (Hamilton et al. 2009).

The infrared spectrum was recorded with a Thermo Nicolet 380 FT-IR apparatus equipped with Smart Orbit Diamond ATR system (Wolkers et al. 2004, Martín-Ramos et al. 2016).

Samples. Fruits of calafate, from Tortel, Aysén, Chile $\left(47^{\circ} 50^{\prime} 00^{\prime \prime} \mathrm{S}, 73^{\circ} 34^{\prime} 00^{\prime \prime} \mathrm{W}\right)$, were collected in January 2015. Seeds were separated from pulp, air dried at $25^{\circ} \mathrm{C}$ for two weeks in the dark, ground and sieved. Seeds of rosa mosqueta, with the same origin as calafate, were obtained by the same process. Seeds of the oil palm tree (palm kernel in the article) were supplied by Cia Refinadora da Amazônia (Belém, Pará, Brazil), part of Agropalma group.

\section{RESULTS}

Vibrational characterization. Additional information to that described in the introduction can be gained by FTIR spectroscopy. Figure 1 shows the ATR-FTIR spectrum and table 1 summarizes the assignments of the main bands to the different components of calafate seeds: vegetal oils, proteins and carbohydrates. Seeds from rosa mosqueta and kernel from palm oil have been included for comparison purposes.

Almost all the bands in the calafate seeds spectrum appear at slightly higher wavenumbers than those of the other seeds used for comparison purposes (except for the bands at 3,300,1,440,1,140 and $810 \mathrm{~cm}^{-1}$ ). The differences should be referred to the different contents of immediate principles, to the differences in the interaction of proteins

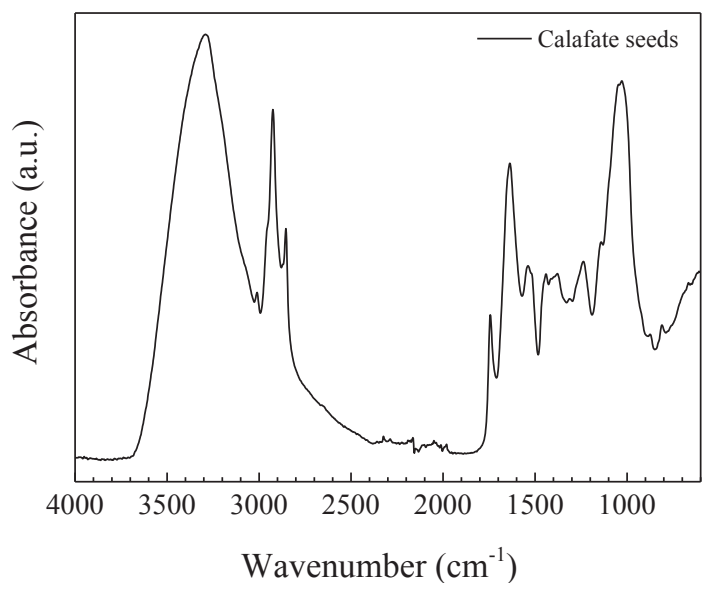

Figure 1. ATR-FTIR spectrum of calafate seeds. Espectro ATR-FTIR de semillas de Berberis buxifolia. 
Table 1. FTIR bands assignments. Wavenumbers are in $\mathrm{cm}^{-1}$.

Asignaciones de las bandas FTIR. Los números de onda se expresan en $\mathrm{cm}^{-1}$.

\begin{tabular}{|c|c|c|c|}
\hline Calafate seeds & Rosa mosqueta seeds & Palm kernel & Assignment \\
\hline 3,290 & - & 3,349 & $\mathrm{C} / \mathrm{L}-v(\mathrm{OH}), v(\mathrm{C}-\mathrm{H})$ \\
\hline 3,010 & 3,007 & - & $\mathrm{C} / \mathrm{L}-v(\mathrm{C}-\mathrm{H}), v(=\mathrm{CH})$ \\
\hline 2,925 & 2,920 & 2,921 & $\mathrm{~L}$ - asymmetrical $v(\mathrm{C}-\mathrm{H})$ \\
\hline 2,854 & 2,850 & 2,852 & $\mathrm{~L}-$ symmetrical $v(\mathrm{C}-\mathrm{H})$ \\
\hline 1,743 & 1,730 & 1,742 & $\mathrm{~L}-v(\mathrm{CO})$ ester carbonyl \\
\hline 1,637 & - & 1,633 & $\mathrm{P}-\mathrm{N}-\mathrm{H}$ bending (amide $\mathrm{I}), v(\mathrm{C}=\mathrm{O})$ \\
\hline- & 1,614 & - & $\mathrm{L} / \mathrm{R}-v(\mathrm{C}=\mathrm{C})$ \\
\hline 1,539 & 1,521 & 1,513 & $\mathrm{P}-\mathrm{N}-\mathrm{H}$ bending (amide II) \\
\hline 1,440 & 1,456 & 1,454 & $\mathrm{~L}-\delta\left(\mathrm{C}-\mathrm{H}_{2}\right)$ bending deform \\
\hline 1,412 & 1,412 & - & $\mathrm{CH}_{2}$ waging, $\mathrm{O}-\mathrm{H}$ in plane deformation \\
\hline 1,379 & 1,371 & 1,377 & $\mathrm{~L}-\delta\left(\mathrm{CH}_{2}\right)_{2}$ bending deformation \\
\hline 1,311 & - & - & $\mathrm{R}-\delta(\mathrm{CH})$ \\
\hline 1,238 & 1,238 & 1,239 & $\mathrm{P}-\mathrm{NH}$ bending (amide III), $\mathrm{O}-\mathrm{H}$ in plane \\
\hline 1,140 & 1,161 & 1,145 & L-methyl ester, $v(\mathrm{CO})$ \\
\hline- & 1,115 & - & $\mathrm{C}-$ starch $\mathrm{OH}$, cellulose \\
\hline 1,045 & 1,049 & 1,063 & $\mathrm{P}$ - ring resonance \\
\hline 1,027 & 1,012 & 1,008 & $\mathrm{M}-\mathrm{PO}_{4}^{3-}$ \\
\hline 875 & - & 870 & $\mathrm{P}$ - amide II \\
\hline 810 & 825 & 804 & $\mathrm{C}-\delta(\mathrm{COC})$ \\
\hline- & 765 & - & $\mathrm{M}-\mathrm{PO}_{4}^{3-}$ \\
\hline- & 718 & 719 & $\rho\left(\mathrm{CH}_{2}\right)_{\mathrm{n}}$ \\
\hline
\end{tabular}

$\mathrm{L}=$ lipids $; \mathrm{M}=$ minerals $; \mathrm{P}=$ proteins $; \mathrm{R}=$ resins $; \mathrm{C}=$ carbohydrates .

with lipids, starch and fiber ( $s c$., the gelation capacity) and to the length of the intermolecular hydrogen bonding (responsible for the stabilization of gels).

Thermal behavior. In the heating cycle (figure 2), the first endotherm, between $-50{ }^{\circ} \mathrm{C}$ and $-10{ }^{\circ} \mathrm{C}$, assigned to lipid phase-transitions, exhibited two peaks: the first, at -28.7 ${ }^{\circ} \mathrm{C}$, corresponds to triglycerides formed by the polyunsaturated fatty acids $\alpha$-LNA and LA, and the second, at -16.2 ${ }^{\circ} \mathrm{C}$, is characteristic of triglycerides formed by monounsaturated fatty oleic acid.

After five freezing-thawing cycles, the endothermic effect was clearly broader than that of the initial run: the first peak was shifted $c a .1 .2{ }^{\circ} \mathrm{C}$ to higher temperatures and the second peak disappeared. Moreover, the enthalpy change was smaller than that of the initial run: $12 \mathrm{~J} \mathrm{~g}^{-1}$ instead of $13.8 \mathrm{~J} \mathrm{~g}^{-1}$ (figure 3).

The main thermal effect at around $110^{\circ} \mathrm{C}$ can be related to gelatinization of starch (an order-disorder transition for the $\mathrm{starch} /$ moisture system).

The endotherm at $204{ }^{\circ} \mathrm{C}$ indicates seed protein crystallization to $\beta$-crystals accompanied by the random-coil $\rightarrow$ $\beta$-form conformational transition.

The chain of thermal events above $235^{\circ} \mathrm{C}$ began with that related to the oxidation reactions (effect with a maximum at $247{ }^{\circ} \mathrm{C}$ ), followed by those attributed to the degradation of hemicellulose and other fiber components (302 ${ }^{\circ} \mathrm{C}$ ) and by those associated with the decomposition of the polyunsaturated $\alpha$-LNA and LA $\left(357^{\circ} \mathrm{C}\right)$ and monounsaturated oleic acid $\left(391^{\circ} \mathrm{C}\right)$ triglycerides. 


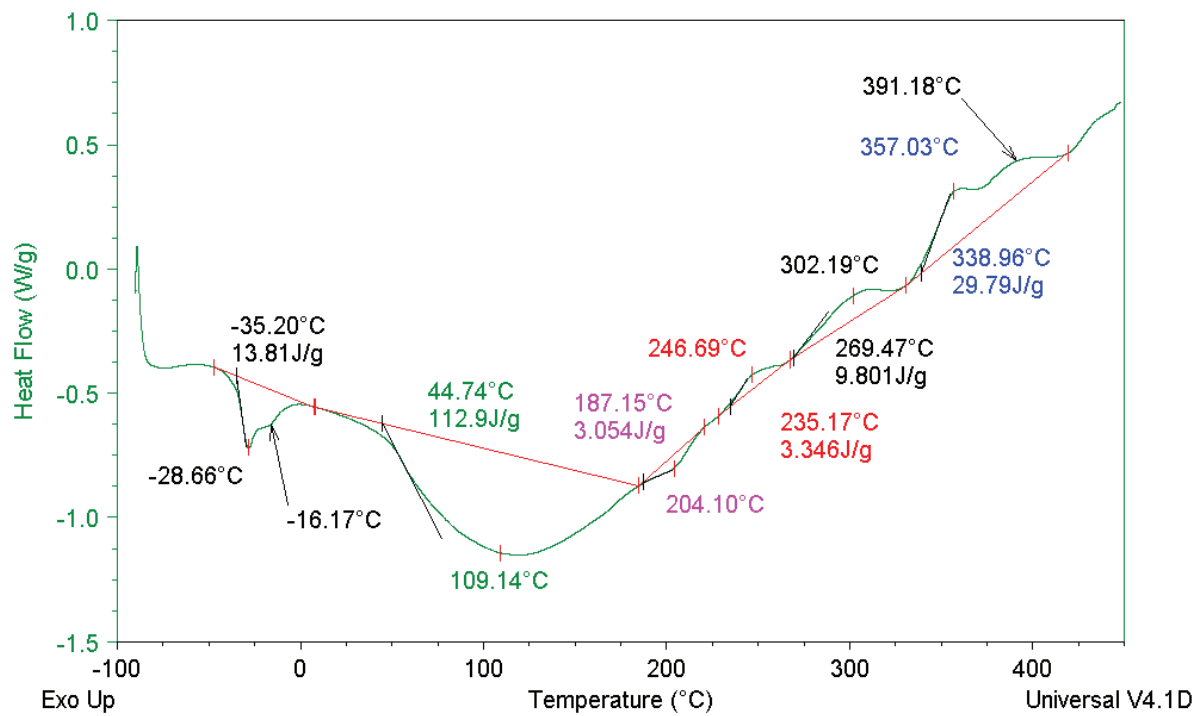

Figure 2. DSC scan of calafate seeds. Different label colors have been used for each of the thermal effects to facilitate their identification.

Registro DSC de semillas de Berberis buxifolia.

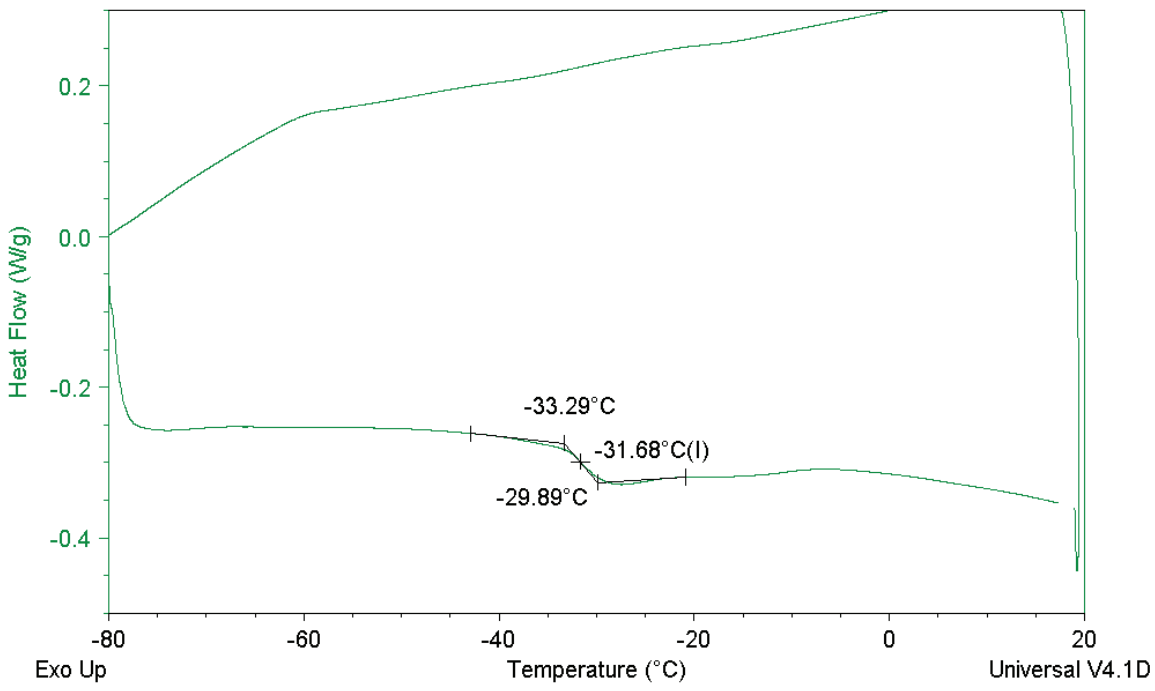

Figure 3. Study of glass transition. Details on the low temperature endotherm after five freezing-thawing cycles.

Estudio de la transición vítrea. Detalles del endotermo a baja temperatura tras cinco ciclos de congelación-descongelación.

\section{DISCUSSION}

Thermal characterization. The results for the low temperature thermal characterization of calafate seeds were in reasonably good agreement with the findings of Nzikou et al. (2006) on Abelmoschus esculentus (L.) Moench (okra or gumbo) seeds and from Ueno et al. (2000) for pure unsaturated fatty acids. High temperature results were also in agreement with those previously reported for pure fatty acids: according to Litwinienko and Kasprzycka-Guttman (1998), and Musialik and Litwinienko (2007), the thermoxidation of pure $\alpha$-LNA occurs at around $250{ }^{\circ} \mathrm{C}$; and according to
Santos et al. (2002), the decomposition for polyunsaturated and monounsaturated fatty acids takes place in the 300 to $380{ }^{\circ} \mathrm{C}$ and in the 380 to $480{ }^{\circ} \mathrm{C}$ ranges, respectively.

Tolerance to low temperature exposure. It is known that vegetal seeds show different longevity when stored at low temperatures, typically at $-20^{\circ} \mathrm{C}$. In several vegetal species seeds, peak lipid-melting temperatures above $27{ }^{\circ} \mathrm{C}$ have been associated with sensitivity to storage at $-18^{\circ} \mathrm{C}$, whereas those with melting temperatures below $27^{\circ} \mathrm{C}$ (e.g., calafate seeds) tolerated low-temperature exposure (Crane et al. 2003). This was further reinforced by the fact that sen- 
sitive species had high concentrations of lauric and myristic acids, while species with high concentrations of unsaturated fatty acids (such as calafate and rosa mosqueta) resisted low-temperature exposure. The cold-acclimated calafate seeds showed an unusual ratio of polyunsaturated (linolenic and linoleic acids) to saturated (palmitic acid) acids of $6.1: 1$ (for comparison purposes, this ratio for palm kernel is $0.016: 1)$. The correlation between cold hardiness and unsaturated fatty acids suggests that unsaturated fatty acids may play a key role in membrane fluidity during seed development (Bafeel and Matta 2004, Leopold et al. 2008). This may be explained as follows:

When cooled to low temperatures $\left(-100^{\circ} \mathrm{C}\right.$ in our assays and $-20^{\circ} \mathrm{C}$ in Patagonian climate), lipid reserves from cotyledons of seeds would display polymorphic crystalline structures. According to Ueno et al. (2000), (i) the phase-transitions involve three polymorphs in LA and two polymorphs in $\alpha$-LNA, and (ii) the higher- and lowertemperature forms in LA and $\alpha$-LNA show orthorhombic $\mathrm{O}^{\prime}{ }^{\prime}+\mathrm{O}$-like and $\mathrm{O}^{\prime}$, subcells, which are similar to those of $\alpha$ - and $\gamma$-forms of mono-unsaturated fatty acids, respectively. However, the ability to form $\alpha$-crystals, which is an indicator of membrane dynamics and cell proliferation, would only appear (progressively) during seed development. It can be inferred that, during the winter, the successive freezing-thawing cycles may lead to increased formation of $\alpha$-crystals of LNA and LA triacylglycerols from $\beta$ or other lower-temperature polymorphs into the liposomal membrane. This process would barely modify the phasetransition temperature of the lipid membrane (as it can be observed in DSC scans, figure 3) but would lead to an increase in the membrane fluidity (LNA would make the cell membranes more fluid than LA (Fukui et al. 1994)).

The function of carbohydrates may be in relation with the length of the intermolecular hydrogen bonding. If, according to Wolkers et al. (2004), the wavenumber position of $\mathrm{OH}$ characterizes the length of the intermolecular hydrogen bonding (a relatively high wavenumber position reflecting a greater length), the relatively low wavenumber of $v(\mathrm{OH})$ at $3,290 \mathrm{~cm}^{-1}$ (for example, for palm kernel it appears at $3,349 \mathrm{~cm}^{-1}$ ) would be indicative of low hydrogen bonding strength. This hydrogen bonding type should make an organism relatively sensitive to temperature fluctuations, which is not the case. The low amount of fiber in calafate seeds $(4.7 \%$ vs. $7.8 \%$ in rosa mosqueta and $9 \%$ in palm kernel) could be the limiting factor for the cytoplasm gelation.

For the above mentioned reasons, it seems that processes in membranes rather than in the glassy cytoplasm may determine the cooling resistance.

\section{CONCLUSIONS}

The features reported in this paper support that physical characteristics of lipid reserves of $B$. buxifolia cotyledons affect seed storability. The correlation between unsa- turated fatty acids and cold hardiness suggests that unsaturated fatty acids may play a key role in vegetal membrane fluidity. The thermal analysis results presented herein suggest that, in winter, successive freezing-thawing cycles may lead to increased formation of linoleic and $\alpha$-linolenic crystals in the liposomal membrane and that this process can cause an increase in the membrane fluidity. Further research on other cold-tolerant plants is under way.

\section{REFERENCES,}

Akinyeye RO, EI Adeyeye, O Fasakin, A Agboola. 2011. Physico-chemical properties and anti-nutritional factors of palm fruit products (Elaeis guineensis Jacq.) from Ekiti State Nigeria. Electronic Journal of Environmental, Agricultural and Food Chemistry 10:2190-2198

Bafeel S, F Matta. 2004. The Relationship Between Fatty Acid Composition and Cold Hardiness of Pecan Cultivars. HortScience 39:858-858

Correa MN. 1984. Flora patagónica, Vol. 8. Buenos Aires, Argentina. INTA. p. 330-340.

Crane J, A Miller, JW Van Roekel, C Walters. 2003. Triacylglycerols determine the unusual storage physiology of Cuphea seed. Planta 217:699-708. DOI: 10.1007/s00425-0031036-1.

Dourado F, P Vasco, FM Gama, MA Coimbra, M Mota. 2000. Characterisation of Rosa Mosqueta seeds: cell wall polysaccharide composition and light microscopy observations. Journal of the Science of Food and Agriculture 80:1859-1865. DOI: $\quad 10.1002 / 1097-0010(200010) 80: 13<1859:: A I D-$ JSFA715>3.0.CO;2-Q.

Freile ML, F Giannini, M Sortino, M Zamora, A Juarez, S Zacchino, D Enriz. 2006. Antifungal Activity of Aqueous Extracts and of Berberine Isolated from Berberis heterophylla. Acta Farmacéutica Bonaerense 25:83-88

Fukui H, T Sato, J Sunamoto. 1994. Physicochemical Perturbation of a-Linolenic Acid Related to Cell Proliferation. Bulletin of the Chemical Society of Japan 67:2213-2218. DOI: 10.1246/bcsj.67.2213.

Hamilton KN, SE Ashmore, HW Pritchard. 2009. Thermal analysis and cryopreservation of seeds of Australian wild Citrus species (Rutaceae): Citrus australasica, C. inodora and $C$. garraway. CryoLetters 30:268-279

Ladio AH. 2001. The maintenance of wild edible plant gathering in a Mapuche community of patagonia. Economic Botany 55:243-254. DOI: $10.1007 / \mathrm{bf02864562.}$

Leopold AC, WQ Sun, I Bernal-Lugo. 2008. The glassy state in seeds: analysis and function. Seed Science Research 4:267274. DOI: $10.1017 / \mathrm{s} 0960258500002294$.

Litwinienko G, T Kasprzycka-Guttman. 1998. The Influence of some Chain-Breaking Antioxidants on ThermalOxidative Decomposition of Linolenic Acid. Journal of Thermal Analysis and Calorimetry 54:203-210. DOI: 10.1023/A:1010189507864.

Martín-Ramos P, J Martín-Gil, MC Ramos-Sánchez, LM NavasGracia, S Hernández-Navarro, FJ Martín-Gil. 2016. Vibrational and thermal characterization of seeds, pulp, leaves and seed oil of Rosa rubiginosa L. Boletín de la Sociedad Argentina de Botánica. 51(3): 419-429.

Mazzuca M, SA Miscoria, E Rost, VT Balzaretti. 2005. Fatty 
Acids and sterols in seeds from wild species of Berberis in Argentine Patagonia. Anales de la Asociacion Quimica Argentina 93:241-246

Musialik M, G Litwinienko. 2007. DSC study of linolenic acid autoxidation inhibited by BHT, dehydrozingerone and olivetol. Journal of Thermal Analysis and Calorimetry 88:781-785. DOI: 10.1007/s10973-006-8507-0.

Nzikou JM, M Mvoula-Tsieri, E Matouba, JM Ouamba, C Kapseu, M Parmentier, D S. 2006. A study on gumbo seed grown in Congo Brazzaville for its food and industrial applications. African Journal of Biotechnology 5:2469-2475

Pitta-Alvarez S, F Medina-Bolivar, M Alvarez, A Scambatto, P Marconi. 2008. In vitro shoot culture and antimicrobial activity of Berberis buxifolia Lam. In Vitro Cellular \& Developmental Biology - Plant 44:502-507. DOI: 10.1007/ s11627-008-9136-z.

Rapoport EH, A Ladio, EH Sanz. 1999. Plantas nativas comestibles de la Patagonia Andina: argentino-chilena, Vol. 1. Bariloche, Argentina. Universidad Nacional del Comahue, National Geographic Society. 81 p.

Rapoport EH, A Ladio, EH Sanz. 2003. Plantas nativas comestibles de la Patagonia Andina: argentino-chilena, Vol. 2.
Bariloche, Argentina. Universidad Nacional del Comahue. $79 \mathrm{p}$.

Ratera EL, MO Ratera. 1980. Plantas de la flora argentina empleadas en medicina popular. Buenos Aires, Argentina. Hemisferio Sur. 189 p.

Santos JCO, IMG Santos, AG Souza, S Prasad, AV Santos. 2002. Thermal stability and kinetic study on thermal decomposition of commercial edible oils by thermogravimetry. Journal of Food Science 67:1393-1398. DOI: 10.1111/j.13652621.2002.tb10296.x.

Sztarker ND, P Cattaneo. 1976. Chemical composition of Berberis buxifolia Lam. (calafate) ripe fruits. Anales de la Asociacion Quimica Argentina 64:281

Ueno S, A Miyazaki, J Yano, Y Furukawa, M Suzuki, K Sato. 2000. Polymorphism of linoleic acid (cis-9, cis-12-Octadecadienoic acid) and $\alpha$-linolenic acid (cis-9, cis-12, cis15-Octadecatrienoic acid). Chemistry and Physics of Lipids 107:169-178. DOI: 10.1016/s0009-3084(00)00169-9.

Wolkers WF, AE Oliver, F Tablin, JH Crowe. 2004. A Fouriertransform infrared spectroscopy study of sugar glasses. Carbohydrate Research 339:1077-1085. DOI: 10.1016/j. carres.2004.01.016.

Recibido: 24.11 .15

Aceptado: 27.04.16 